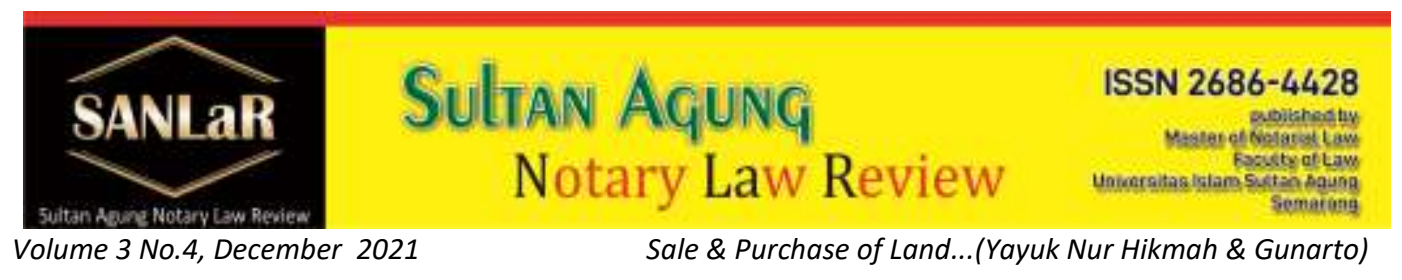

\title{
Sale \& Purchase of Land Under Hand With Testimony Sign by Village Head or Customary Head
}

\author{
Yayuk Nur Hikmah") and Gunarto**) \\ *) Faculty of Law, Universitas Islam Sultan Agung (UNISSULA) Semarang, E-mail: \\ yayuknurhikmah@gmail.com \\ *) Faculty of Law, Universitas Islam Sultan Agung (UNISSULA) Semarang, E-mail: \\ gunarto@unissula.ac.id
}

\begin{abstract}
Land has a very important relationship and meaning for human life. Land is an immovable object or a fixed object whose ownership is regulated by the prevailing laws and regulations in Indonesia. Including the transfer of land rights due to buying and selling, the transfer of land from the seller to the buyer must use a valid or authentic proof of transfer made by the official making the land deed. In accordance with the laws and regulations. This study uses sociological juridical research methods, descriptive research specifications, aims to describe a problem in a certain area or at a certain time. This study uses secondary data sources which are divided into primary law, secondary law and tertiary law. The research results that have been collected are then analyzed qualitatively. The formulation of the problem was analyzed using the theory of legal certainty, the theory of usefulness or legal expediency, and the theory of legal justice. Based on the results of the study, it can be concluded, buying and selling land under the hands is still often done because people are not aware of the law of buying and selling land and the importance of proof of the transfer of land rights. The process of implementing the sale and purchase of land in the presence of the Village Head or Customary Head in Seruyan Regency is the parties coming to the village head's office and requesting a transfer of sale and purchase letter or proof of transfer of land rights to the village head and bring the conditions determined by the Village Head. The solution so that land registration can be carried out is that the process of buying and selling land must be carried out again in the presence of PPAT.
\end{abstract}

Keywords: Buying; Land; Registration; Selling; Transfer.

\section{Introduction}

In Indonesia, based on the provisions of Article 1 (paragraph 4) of the Basic Agrarian Law of the LoGA, land in a juridical sense is the surface of the earth, 
while land rights are rights to a certain portion of the earth's surface which are limited, two-dimensional in length and width. Land is given to the right holder, with the rights provided by the LoGA being used and exploited. ${ }^{1}$

Land rights currently in force in Indonesia are one of the things regulated in Agrarian Law and are based on the existence of customary law. That land is a very valuable and important asset at this time as well as many problems that arise and originate from land rights. To anticipate and prevent problems that may arise, the owner of the right needs to register the land that is his right so that he has legal certainty over the land so that there are no adverse disputes in the future. The land rights of a plot of land must be registered because by registering the rights to the land that we own, our ownership of the plot of land has legal force so that it has legal certainty. ${ }^{2}$

The types of land tenure rights in the National Land Law, especially those included in individual rights, include: Land rights (Article 4) consist of two, among others: primary: property rights, cultivation rights, building occupancy rights, granted by the state, and use rights, which are granted by the state (Article 16), Secondary: building rights and use rights granted by land owners, liens, profitsharing business rights, ride rights, rental rights and others (Articles 37, 41 and 53) Waqf $^{3}$ (Article 49), security rights to land: Mortgage Rights (Articles 23, $33,39,51$ and Act No. 4 of 1996). ${ }^{4}$

Providing legal certainty in the land sector requires: First, the availability of written legal instruments, which are complete and clear and implemented consistently; second, the implementation of effective land registration.

With the availability of written legal instruments, anyone with an interest will easily find out what possibilities are available for him to control and use the land he needs, how to obtain it, what rights, obligations and prohibitions exist in controlling land with rights. certain sanctions, what sanctions he faces if the relevant provisions are ignored, as well as other matters relating to the control and use of the land he owns.

In the event that a person needs land, from the legal provisions he knows how to obtain it and what will be the evidence. If the land in question has the status of property rights, he will know that the land in question can be controlled and

\footnotetext{
${ }^{1}$ Ngadino, (2019), Ketentuan Umum Tata Cara Pembuatan Dan Pengisian Akta PPAT, Semarang: UPGRIS Press, p.46

${ }^{2}$ Ibid, p.47

${ }^{3}$ Sukarmi, S., \& Victoria, Argo. (2018). Cash Waqf in Sustaining of Indonesian Society "In Legal \&amp; Economic Perspective". AL-ITQAN: JOURNAL OF ISLAMIC SCIENCES AND COMPARATIVE STUDIES, IRKHS-IIUM, Malaysia, 2(1), 83-97. https://doi.org/10.31436/al-itqan.v2i1.43

${ }^{4}$ Boedi Harsono, (2008), Hukum Agraria Indonesia, Jakarta: Djambatan, p. 264
} 
used indefinitely. If he needs money, from the legal provisions in question, he knows that his land can be used as collateral by being encumbered with security rights. Also that the land can be sold to other parties. If the land is agricultural land, from the provisions of the regulations governing in Indonesia, he will know that he will be required to reside in the sub-district area where the land he purchased is located. He will also know what sanctions he will face if he does not fulfill these obligations.

For someone who is going to buy land knowledge of these things, however important it is not enough to arrive at the decision to buy the land that is offered to him. He wants to get certainty first, which land he will buy is land, where is it located, what are the boundaries, how big is it, what buildings and/or plants he has on it. What is also no less important is to obtain certainty regarding the status of the land, who is the holder of the rights and or the absence of rights of other parties. All of these are needed by him to secure the purchase to be made and prevent disputes from arising in the future.

In rural communities, namely in Suka Makmur village, Central Seruyan District, Seruyan Regency, with a small area and a small number of residents, the absence of land registration in daily life does not feel like a deficiency. Because in this limited area and population, people actually know each other about the land owned by their fellow citizens, which in general is customary land.

In such an environment of indigenous peoples, land registration is not yet perceived as necessary, but with economic developments that are increasingly intensive, contact with rural communities will also require information support through land registration activities. ${ }^{5}$

The transfer of rights or transfer of rights is a legal act that aims to transfer rights. Which can be done by means of the transfer of rights through, among other things: buying and selling, exchanging, grants, separation and distribution of joint assets, income in the company or inbreng and others.

The transfer of rights mentioned above must be made authentically in order to provide proof of legal rights or ownership and have permanent legal force. So that you don't have to worry in the future if there is a conflict.

As stated in Article 37 (paragraph 1) of PP No. 24/1997 which reads: "The transfer of land rights and ownership rights to apartment units through buying and selling, exchanging, grants, entry of company data and legal acts of transferring rights due to auction can only be registered if it is proven by a deed

${ }^{5}$ Ibid p. $69,70,71 \& 72$ 
made by the authorized PPAT. according to the provisions of the applicable laws and regulations."

This is reinforced by government regulation Number 37 of 1998, concerning the Regulation of Land Deed Maker Officials (PPAT) in Article 2 (paragraph 1) which reads as follows:

"PPAT has the main task of carrying out some land registration activities by making a deed as evidence that certain legal actions have been carried out regarding land rights or property rights to flat units which will be used as the basis for registering changes in land registration data resulting from the legal act." 6

So the sale and purchase of land rights must be carried out before the official making the land deed (PPAT). This is as evidence that there has been a sale and purchase of land rights and then the land certificate maker official (PPAT) makes a deed of sale and purchase which is then followed by registration at the local land office according to the location of the land.

However, it is undeniable that in everyday people's lives there are still many land sales and purchases carried out between sellers and buyers without the intervention of land deed officials. The act of buying and selling under the hands is sometimes only proven by a receipt as evidence that a sale and purchase has taken place, there are also those who use a sale and purchase agreement with a testimony by the village head with a stamp. Because of the use of stamps and testimony from the village head, the community thought it was strong evidence. For reasons of ignorance, on the basis of trust, and wanting convenience in buying and selling transactions so that buying and selling occurs under the hands. Not a few people who only have proof of ownership of land that is still in the name of the old owner (the seller).

The certificate guarantees legal certainty regarding the person who is the holder of land rights, legal certainty regarding the location of the land, the boundaries and area of a plot of land, and legal certainty regarding the rights to his land. Legal certainty can be given legal protection to the person whose name is listed in the certificate against interference from other parties. ${ }^{7}$

One of the consequences of buying and selling land under the hands of a problem arises when the buyer will do Land Registration. In the land registration

\footnotetext{
${ }^{6}$ Boedi Harsono, (2002), Hukum Agraria Indonesia Himpunan Peraturan-Peraturan Hukum Tanah, Jakarta: Djambatan, p. 539.

${ }^{7}$ Sutedi, Adnan. (2006). Legal Provisions for Applicability of Certificates as Evidence of Land Rights. Jakarta: Cipta Jaya, p. 23
} 
process, proof of the transfer of land rights is needed, namely a legal sale and purchase deed according to law made by PPAT. The proof of the transfer is a requirement in carrying out land registration. The proof of the transfer of rights can only be registered if it is proven by a deed made by the authorized PPAT according to the provisions of the applicable laws and regulations.

\section{Research Methods}

This study uses sociological juridical research methods, descriptive research specifications, aims to describe a problem in a particular area orcertain moment. This study uses secondary data sources which are divided into primary law, secondary law and tertiary law. The research results that have been collected are then analyzed qualitatively. The formulation of the problem was analyzed using the theory of legal certainty, the theory of usefulness or legal expediency, and the theory of legal justice.

\section{Results and Discussion}

3.1. The Causes of Selling and Buying Land Under the Hands With Testimonials from the Village Head or Customary Heads Are Often Done By The Community In Seruyan Regency

Based on the results of research that researchers conducted in the field, namely in the Seruyan Regency Region, precisely in the village of Suka Makmur against residents, researchers found data and facts about several cases regarding buying and selling land under the hands of the testimony of the Village Head or Customary Head which is often carried out by the community in the area of Seruyan District.

Because of the large number of cases of residents who became the object of research in Seruyan Regency, the researchers used a purposive sampling method, namely taking 3 residents as samples to represent the entire community who bought and sold land under their hands with the testimony of the Village Head or Customary Head.

In order to find out the reasons or reasons put forward by the residents, namely by the seller and the buyer who carried out the legal struggle for the sale and purchase, the researcher also conducted interviews with the Suka Makmur Village Head who often made the buying and selling letters. In general, in the Seruyan Regency area, especially in Suka Makmur Village, when conducting land sales and purchase transactions, most people still do it under their hands, which is made in front of the village head and the village head's signature is known. In fact, the community also does a lot of buying and selling transactions without the village head's testimony, only involving both parties, the seller and the buyer with proof of receipt signed on stamp duty. Factors that influence people to buy and sell land under their hands include: 
a. Not aware of the law of buying and selling land. Meanwhile, according to the law or the validity of the act of buying and selling land, authentic or valid proof of the transfer of sale and purchase can only be made before the authorized official, namely PPAT, only causing the transfer of ownership of the land from the ownership of the seller's rights to the buyer so that it has legal and perfect evidentiary power. Authentic proof of transfer of land rights is also a requirement for land registration. So it is very important to transfer land rights because buying and selling is made authentically.

b. Based on mutual trust between the seller and the buyer, because they know each other between the seller and the buyer, they feel that buying and selling land under their hands is enough, not thinking about problems that can arise in the future.

c. The cost factor, the community's finances are not the same, there are those who object to the costs that must be incurred to carry out land registration.

d. The estimation of a long time, the transition process of buying and selling land carried out in front of PPAT takes time because of various processes that must be passed, so that people prefer to do it under their hands, the process is faster and does not wait long.

e. Distance, the distance traveled by the PPAT office from the residence of the parties who are far away. Due to the lack of PPAT offices in Seruyan Regency.

f. Convoluted, complicated rename process.

According to the researcher, it is necessary to disseminate information to the community regarding the importance of authentically transferring land rights before PPAT.

The sale and purchase of private land based on the theory of legal certainty does not have legal certainty because since the enactment of Government Regulation Number 10 of 1961 concerning land registration, land sales and purchases can only be carried out in the presence of PPAT. So that there has been a transfer of rights from the seller to the buyer and the parties get legal protection for the rights and obligations of the parties.

The right of the seller to receive the price of the goods he has sold from the buyer in accordance with the price agreement between the two parties. Meanwhile, the Seller's Obligations are as follows:

1. Give up ownership of the goods being traded. The Civil Code recognizes three types of objects, namely movable objects, immovable objects and immovable objects, so the transfer of ownership rights also applies to each of these items:

a. The delivery of movable objects concerning the delivery of movable objects is contained in article 612 of the Civil Code "Submission of movable 
objects, except for those that are not bodily, is carried out by real delivery of the objects by or on behalf of the owner, or by handing over the keys from the building, where the object is located". ${ }^{\circ}$

Submission Levering of movable objects (Feitelijk Levering) is a real surrender. Legally, land is an immovable object or a fixed object so that the buying and selling process is different from when buying movable objects such as motorcycles, cars and others. Where legally buying and selling is done in cash and instantly. This means that if you have agreed on the price, the money is handed over and the seller gives the goods and it happens instantly. However, it is different from buying and selling land as immovable property which requires an authentic deed. An authentic deed is a deed made by a land deed official or an official authorized to make a deed of sale and purchase.

b. Submission of Immovable Objects

Regarding the delivery of immovable objects, it is regulated in Article 616-620 of the Civil Code, namely: Article 616 "Submission or appointment of immovable objects is carried out by announcement of the deed in question in the manner as specified in article 620. For land, it is done by PPAT Deed while others are done by notarial deed.

According to Civil Law, the surrender of a fixed object or immovable object, namely land, must be carried out by Juridische Levering (legal handover). It is the surrender or transfer of material rights for fixed objects that must be carried out in the presence and assistance of a public official who has the authority to do so. The legal handover is carried out to provide legal certainty, because land issues are prone to conflict or dispute. So that the transfer of land rights when using an underhand sale and purchase agreement is feared in terms of evidence that it does not have strong legal force and can be denied by one of the parties when submitted as evidence. It would be nice to be authentically made. The authentic deed does not only include the parties involved in the sale and purchase transaction, but also includes the role of the authorized official, namely PPAT.

The difference between authentic and underhand is from the strength of the proof, namely the process of proving in court. Authentic has strong and perfect power, meaning that there is a stamp signature and the presence of an authorized legal official in it for that to be a strong and unavoidable basis if there is bad faith on one of the parties to deny the contents of the agreement.

c. Submission of Intangible Objects is regulated in article 613 of the Civil Code which states that the submission of receivables on behalf is carried out by a notarial deed or an underhand deed which must be notified to the debtor in writing, approved and acknowledged.

2. Bear the comfort of the goods and bear the hidden defects.

8 http://ilmu Hukum56.blogspot.co.id/2015/04/makalah-percepatan-jual-beli-berserta.html, accessed on October 24, 2021, at 1:24 WIB 
Article 30 to article 52 of the United Nations Convention on Contracts for the International Sale of Goods regulates the main obligations of the seller, namely as follows:
a. Handing over goods
b. Submit documents
c. Transferring Ownership

The right of the Buyer is to receive the goods he has purchased, both real and juridical. The United Nations Convention on Contracts for the International Sale of Goods regulates obligations between the seller and the buyer. Articles 53 to 60 of the United Nations Convention on Contracts for the International Sale of Goods regulate the obligations of the buyer.

There are 3 main obligations of the buyer, namely:

1. Checking the goods sent by the Seller

2. Pay the price of goods according to the contract

3. Accept delivery of goods as stated in the contract

The buyer's obligation to pay the price of the goods includes the act of taking steps and completing with the formalities that may be required in the contract or by laws and regulations to enable the execution of the payment. Place of payment at a place agreed by both parties. The Buyer's Obligations are:

a. Pay the price of the goods purchased according to the promise that has been made.

b. Bear the costs incurred in buying and selling, for example delivery fees, deed fees and so on unless agreed otherwise.

Therefore, it can be concluded that the obligations of the buyer are the rights of the seller and vice versa the obligations of the seller are the rights of the buyer. In terms of usefulness or usability in the process of buying and selling land under the hands, it contains only a few benefits for the seller and the buyer, namely in terms of the ease of making buying and selling transactions. However, if in the future there is an unexpected conflict, both the seller and the buyer will suffer losses, because they do not have legal certainty and do not have legal protection to prevent the possibility of arbitrary actions from any party.

Meanwhile, in terms of fairness, buying and selling land under the hands does not provide justice for the buyer. That the possibility of arbitrary actions from various parties, the buyer does not have legal certainty, so he does not have legal protection. Against evidence or as evidence of ownership before the court. Because the land certificate is still in the name of the seller. The seller has the responsibility to make an authentic deed made before the authorized official for the benefit of the buyer which the seller does not do for the buyer. That the deed of sale and purchase made before an authorized official as a condition for registering land or changing the name of a certificate. 
There are still many people who buy and sell land under their hands without paying attention to the letters such as certificates or other proof of land ownership. Even daring to buy and sell land with an underhand agreement made only by both parties, with proof of receipt and signature on stamp duty on the basis of trust in the seller and buyer parties.

\subsection{The process of implementing the sale and purchase of land in front of the village head or customary head}

The implementation of buying and selling which is usually done by the community, they have made a sale and purchase first, namely making the delivery and acceptance of the sale and purchase after that the new parties came to the village head's office and asked for a transfer of sale and purchase letter or proof of the transfer of land rights to the village head. . The sale and purchase of land before the village head is usually carried out with the following conditions:
a. There is a seller and a buyer
b. Certificate or proof of land ownership
c. Witness
d. ID cards of all parties
e. KK for the seller and the buyer

Considering that in the sale and purchase letter made by the village head it contains the names of the parties, addresses, place of birth date and certificate number, in the name of the certificate and the address of the land being traded. With the above conditions, the process of buying and selling land in front of the village head can be carried out. The authority of the village head in the buying and selling process is only known to be witnessed by witnesses so that the ownership of the land according to the law has not changed ownership where the land certificate is still in the name of the seller.

As for residents who have not acknowledged the existence of the Village Government in the process of buying and selling land, they come to the office of the Village Head by directly bringing a buying and selling letter made by themselves and asking for the Village Head's signature. So that the village head refused to sign the letter that he made himself because according to the village head he did not make the letter regarding the archive so that the village did not have an archive of the sale and purchase letter.

In terms of legal certainty, the process of buying and selling land under the hands is basically legal as long as the sale and purchase fulfills the terms of the agreement, but only applies as a transaction between the parties. The buying and selling process under the hands has fulfilled the requirements for the validity 
of the agreement in Article 1320 of the Civil Code, including:
a. Deal
b. Skills
c. A certain thing
d. A lawful reason

But the sale and purchase of land has been regulated by laws and regulations that the process of buying and selling land can only be carried out in the presence of an authorized official and is a condition for registering land.

In terms of expediency or usefulness of the process of buying and selling land under the hand, it provides benefits, namely it is easy to make buying and selling transactions. Don't have to wait a long time. However, in the aspect of prudence regarding the letters regarding the land, there is no check whether the land does not have a problem.

Meanwhile, in terms of fairness, the process of buying and selling land is fair, namely in the sale and purchase of land under the hands, the process is not complicated and does not wait a long time for the process of buying and selling land to be carried out.

\subsection{The Solution So that Land Registration Can Be Done Given The Evidence of Transfer of Land Rights Is Done Under The Hand With A Testimony Sign By The Village Head Or Customary Head}

Solutions so that land registration can be carried out considering the evidence of the transfer of land rights carried out under the hands with a testimony by the village head or customary head include:

The letter of transfer of land rights which is carried out under the hands is made in front of the village head so that land registration can be carried out, the solution is that it must continue through the PPAT notary who has the authority in terms of the transfer of sale and purchase of land rights, namely the process of buying and selling land in front of the PPAT. The seller and buyer directly face the PPAT to then make a deed of sale and purchase of land.

As for the problems that arise as a result of an underhand sale and purchase letter made in front of the Village Head, if the seller or one of the buyers cannot appear before the PPAT to make another sale and purchase deed of the land. Some of the common reasons that underlie one of the parties being unable to appear are because they died, have moved domicile and or do not know their whereabouts, the seller does not want to be bothered anymore, there are also those who deny that they have sold the land. There is a loss for the buyer if problems occur in the future. So that the buyer should in buying land must carry 
out the process of buying and selling land made by PPAT. And check carefully the seller's proof of land ownership in the form of certificates, and others.

The deed of sale and purchase of land made by PPAT is a requirement for registering land or for recording the name transfer of land certificates from the seller to the buyer. Where in the making of the deed of sale and purchase of land made by PPAT, each of the seller and buyer is obliged to pay transaction taxes. The seller is obliged to pay value added tax (VAT) and the buyer is obliged to pay the land and building rights acquisition fee (BPHTB) according to the provisions of Government Regulation Number 24 of 1997.

If the land sale and purchase transaction occurs in an area where there is no Land Deed Making Official (PPAT), then it can appear before the District head in his position and capacity as a Temporary PPAT. It should be noted that the PPAT that can make the deed of sale and purchase of land is the PPAT who is in the domicile area, namely the one district area with the land object.

The process of making the Deed of Sale and Purchase of Land before PPAT, among others, is as follows:

1. Terms of sale and purchase in front of PPAT

When facing PPAT to make a deed of land sale and purchase agreement, there are several things that need to be prepared by the relevant parties, namely:

a. The seller is expected to bring the following conditions:

1) Original certificate of land rights to be sold

2) KTP (Identity Card)

3) Proof of payment of PBB (Land and Building Tax)

4) Letter of Approval from husband/wife, for those who are already married

5) KK (Family Card)

b. The buyer, brings the following conditions:

1) KTP (Resident Identity Card)

2) KK (Family Card)

3) Payments that can be made in cash before the PPAT, or an order to issue money to the Bank, which have been agreed between the seller and the relevant buyer.

2. Flow of making the Deed of Sale and Purchase of Land

a. Before making the deed of sale and purchase of land made by PPAT, the PPAT must conduct an examination of the authenticity of the certificate to the relevant land office;

b. The seller must pay income tax (PPH), if the selling price of land is above IDR $60,000,000.00$ (Sixty million rupiah) at the bank or the relevant post office;

c. The prospective buyer can make a statement that by purchasing the land he does not become the holder of land rights that exceed the maximum limit provisions;

d. A statement from the seller that the land owned is not in dispute; 
e. PPAT refuses to make a Sale and Purchase Deed, if the land to be sold is in dispute.

3. Making the deed of sale and purchase of land:

a. The making of the deed must be attended by the seller and the prospective buyer, the person authorized by a written power of attorney;

b. The making of the deed must be attended by at least two witnesses;

c. PPAT reads the deed, and explains the contents and purposes of making the deed;

d. If the contents of the deed have been approved by the seller and the prospective buyer, the deed is signed by the seller and the prospective buyer, the witnesses and the PPAT;

e. The deed is made in two original sheets, one sheet is kept at the PPAT office and one sheet is only submitted to the land office, for registration purposes;

f. The seller and buyer are given a copy of each.

The sale and purchase of land if carried out under the hands with testimony or known by the village head, the sale and purchase is not valid if it is carried out after the enactment of Government Regulation Number 24 of 1997 concerning Land Registration, precisely on October 8, 1997 and does not cause the transfer of the land from the seller to the buyer. And vice versa if the manufacture of an underhand sale and purchase letter made before the village head was made before the enactment of government regulation Number 24 of 1997 concerning Land Registration, precisely before October 8, 1997 the sale and purchase was legal according to law and could be used as conditions for land registration.

According to the researcher in terms of legal certainty, land registration for buying and selling land carried out under the hands based on the regulations governing land registration can be done if it fulfills the requirements for land registration, namely buying and selling carried out before the PPAT. If the sale and purchase of land is carried out under the hands, it does not have legal certainty, does not become strong evidence and is a requirement to be able to register land.

In terms of usability or benefits of land registration, it is very beneficial for the parties. Land registration is carried out in order to obtain legal certainty that the land has indeed completely transferred ownership from the seller to the buyer. So that the buyer can take any legal action against the land he has purchased.

In terms of fairness of land registration, the parties achieve justice that the seller and the buyer have received the rights and obligations that should have been owned in the sale and purchase of land. That is, the seller receives his rights, namely the money from the sale and purchase that has been agreed upon while the buyer can fully own the rights to the land he bought. 


\section{Conclusion}

The sale and purchase of land under the hands with the testimony of the village head or customary head is often carried out by the community in Seruyan Regency because the community is not aware of the law of buying and selling land, based on mutual trust between the seller and the buyer, the cost factor, the estimation of a long time, distance and complicated in carrying out the process of making a deed of sale and purchase made by an authorized official, namely PPAT. The process of implementing the sale and purchase of land in the presence of the Village Head or Customary Head in Seruyan Regency is that the seller and the buyer have made a sale and purchase first, namely the delivery and acceptance of the sale and purchase after that the new parties come to the village head's office and ask for a transfer letter to be made sale and purchase or proof of transfer of land rights to the village head and bring the conditions determined by the village head. In the process of making the sale and purchase letters witnessed and signed by witnesses, known and or signed by the Village Head and also signed by the seller and the buyer. The solution so that land registration can be carried out considering that the evidence of the transfer of land rights is carried out under the hand with a testimony by the village head or customary head, that is, the process of buying and selling land must be carried out again before the PPAT.

\section{References}

Journals:

[1] Agrisal Ruslan, Rifan, and Umar Ma'ruf, Community Legal Awareness in the Sale and Purchase of Land with Ppat Deeds in Tinanggea District, South Konawe Regency, Southeast Sulawesi, Vol. 4, No. 3, 2017, p. 428. urls:http://jurnal.unissula.ac.id/index.php/akta/article/viewFile/1817/13 66. Accessed October 15, 2021, 11:31 am

[2] IIham and Djauhari, "Application for Ownership Derived from State Land at the Land Office of Semarang City", Vol. 4, Number 3, p. 360, September 2017,

url:http://jurnal.unissula.ac.id/index.php/akta/article/download/1808/13 57. Accessed On October 16, 2021, Time: 22:58

[3] Karuni Nuranidhira, Irdha and Winanto, Juridical Analysis of the Legal Consequences of Making a Land Sale and Purchase Deed that is not in accordance with the Procedure for Making a Land Deed, KIMU 4, 2020, p. 756.

urls:http://jurnal.unissula.ac.id/index.php/akta/article/download/2532/1 894. Accessed on October 15, 2021, at 12:22

[4] Sukarmi, S., \& Victoria, Argo. (2018). Cash Waqf in Sustaining of Indonesian Society "In Legal \&amp; Economic Perspective". AL-ITQAN: 
JOURNAL OF ISLAMIC SCIENCES AND COMPARATIVE STUDIES, IRKHSIIUM, Malaysia, 2(1), 83-97. https://doi.org/10.31436/al-itqan.v2i1.43

Books:

[1] Boedi Harsono, (2002), Hukum Agraria Indonesia Himpunan PeraturanPeraturan Hukum Tanah, Jakarta: Djambatan

[2] Boedi Harsono, (2008), Hukum Agraria Indonesia, Jakarta: Djambatan

[3] Handoko, Widhi, (2014), Kebijakan Hukum Pertanahan Sebuah Refleksi Keadilan Hukum Progresif, Yogyakarta: Thafa Media

[4] Ngadino, (2019), Ketentuan Umum Tata Cara Pembuatan Dan Pengisian Akta PPAT, Semarang: UPGRIS Press

[5] Sutedi, Adnan. (2006). Legal Provisions for Applicability of Certificates as Evidence of Land Rights. Jakarta: Cipta Jaya

Regulation:

[1] Constitution Republic of Indonesia of 1945;

[2] Code of Civil law;

[3] Act No. 5 of 1960 concerning Basic Regulations on Agrarian Principles;

[4] Government Regulation Number 8 of 1953 concerning State Land Control

[5] Government Regulation of the Republic of Indonesia Number 24 of 1997 concerning Land Registration;

[6] Government Regulation of the Republic of Indonesia Number 24 of 2016 concerning Amendments to Government Regulation Number 37 of 1998 concerning the Regulation of the Position of the Maker of Land Deeds;

[7] Regulation of the Head of the National Land Agency Number 3 of 1997 concerning Provisions for the Implementation of Government Regulation Number 24 of 1997.

Internet:

http://ilmu Hukum56.blogspot.co.id/2015/04/makalah-percepatan-jual-beliberserta.html, accessed on October 24, 2021, at 1:24 WIB 